\title{
High-resolution LiDAR mapping of glacial landforms and ice stream lobes in Finland
}

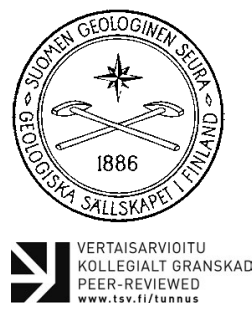

\author{
Niko Putkinen ${ }^{{ }^{*}}$, Nick Eyles ${ }^{2}$, Satu Putkinen ${ }^{1}$, Antti E.K. \\ Ojala $^{3}$, Jukka-Pekka Palmu ${ }^{3}$, Pertti Sarala ${ }^{4}$, Tapio Vä̈̈nänen 5 , \\ Jukka Räisänen ${ }^{4}$, Jouko Saarelainen 5 , Nitna Ahtonen 5 , Hannu \\ Rönty ${ }^{5}$, Arto KiIskinen ${ }^{5}$, Tom Rauhaniemi ${ }^{3}$ and Tapani Tervo ${ }^{5}$ \\ ${ }^{1}$ Geological Survey of Finland, P.O. Box 97, FI-67101, Kokkola, Finland \\ ${ }^{2}$ Department of Physical and Environmental Sciences, University of Toronto \\ at Scarborough, 1265 Military Trail, Scarborough, Ontario M1C 1A4, Canada \\ ${ }^{3}$ Geological Survey of Finland, P.O. Box 96, FI-02151, Espoo, Finland \\ ${ }^{4}$ Geological Survey of Finland, P.O. Box 77, FI-96101, Rovaniemi, Finland \\ ${ }^{5}$ Geological Survey of Finland, P.O. Box 1237, FI-70211, Kuopio, Finland
}

\section{Abstract}

Newly available high resolution airborne LiDAR (Light Detection And Ranging) technology is generating unprecedented next-generation imagery of Earth surface features. LiDAR datasets are being employed by the Geological Survey of Finland (GTK) as part of a new national geological initiative (Glacier Dynamic database: GDdatabase) to rapidly and cost-effectively map glacial landforms and sediments left by the last (Late Weichselian) Fennoscandian Ice Sheet (FIS). There is a high demand for such data in hydrogeological, geoengineering and mineral exploration projects and also for the identification of glacial landforms that provide key information regarding ice sheet rheology, growth and decay. An important step forward with this new technique is the recognition of paleoice stream corridors with fast flowing ice ( $>3 \mathrm{~km} \mathrm{yr}^{1}$ based on modern ice sheets), surrounded by stagnant or sluggish-flowing ice. Precise geomorphic criteria are now available for recognition of paleo-ice streams, based on the elongation of subglacial streamlined bedforms and the presence of megascale glacial lineations. Flow sets of drumlins and megascale glacial lineations can now be mapped in high resolution using LiDAR and are now seen as genetically related forms in a continuum that records increasing ice flow velocity and the creation of a low friction bed. This paper briefly outlines the nature of the GDdatabase and the methodology behind its construction and provides examples of principal bedform types that record the dynamic interplay of paleo-ice stream lobes in the Finnish sector of the last FIS.

Keywords: Finland, LiDAR, glacial geology mapping, paleo-ice streams, Fennoscandian Ice Sheet

*Corresponding author (e-mail: niko.putkinen@gtk.fi)

Editorial handling: Juha Pekka Lunkka (juha.pekka.lunkka@oulu.fi) 


\section{Introduction}

The use of high-resolution airborne Light Detection And Ranging (LiDAR) technology has revolutionized geological and geomorphological mapping (e.g., Johnson et al., 2015). Recent studies have shown that mega-scale landforms, such as drumlins, eskers and end moraine complexes, are revealed on LiDAR-based digital elevation models (DEM) in much greater detail than from traditional mapping and air photographic interpretation, and in addition, landforms that are smaller than hitherto resolved from conventional topographic maps and $10 \mathrm{~m}$ grid DEMs (e.g., small annual moraine ridges) can now be detected and mapped using LiDARbased DEMs (e.g., Greenwood et al., 2015; Eyles et al., 2016; Dowling et al., 2016; Ojala, 2016).

Concurrent with advances in imaging technology, significant new understanding of paleo ice sheets has come about as a result of the recognition of corridors ('arteries') of fast flowing ice surrounded by sluggish flowing or stagnant ice. This is based on analysis of subglacial streamlined bedforms such as drumlins and their more elongate companions referred to as Mega-Scale Glacial Lineations (MSGLs). The last North American ice sheet (Laurentide) had at least 100 such ice streams and it is now apparent that the many 'lobes' hitherto recognized in Scandinavia are the expression of fast-flowing ice streams within the FIS (e.g., Boulton et al. 2001; Rydningen et al., 2013; Greenwood et al., 2015).

In Scandinavia, high-resolution DEM and LiDAR imagery has been employed to study a wide range of geomorphological features such as De Geer recessional moraines (Bouvier et al., 2015; Ojala et al., 2015; Dowling et al., 2016; Ojala 2016), ribbed and hummocky moraine areas (Möller \& Dowling, 2015), subglacial meltwater systems (Sarala et al., 2015), beach ridges, cliffs and shore terraces (Ojala et al., 2013), fluvial terraces, floods plains, lateral meltwater channels (Eilertsen et al., 2015), postglacial fault scarps and landslides, and surface features related to paleoseismic events (e.g. Sutinen et al., 2014; Mikko et al., 2015; Palmu et al., 2015), together with bedrock lineaments, fracture sets and fissures (Scheiber et al., 2015; Skyttä et al., 2015).
The technology has not only allowed significant advances in understanding the spatial occurrences and patterns of glacial and accompanying landforms - and possibly also their origin(s), but the development of LiDAR-based mathematical solutions and models to underpin field-based observations (Yu et al., 2015; Sookhan et al., 2016).

The availability of LiDAR DEMs has fundamentally changed the process of mapping Quaternary deposits (Putkinen et al., 2016). It has greatly reduced the duration of expensive field work and mapping time in general, proving an indispensable and convenient tool that is highly cost-effective. In Finland, this possibility has initiated the development of a new national geologic database in order to combine and store pre-existing data of superficial Quaternary deposits and landforms (Glacier Dynamic database or GDdatabase). The purpose is to produce completely new LiDAR imagery-based coverage of the country, focusing on the record of ice sheet dynamics during the last ice age. In addition to producing LiDAR DEMs collected by the National Land Survey of Finland (http://www.maanmittauslaitos.fi/en/professionals/ topographic-data/remote-sensing/laser-scanning), the project aims at producing a wide selection of Quaternary geological map databases by the Geological Survey of Finland, and also specific themes which cover Finland partly or completely at scales varying between $1: 10000$ and $1: 1000000$.

\subsection{Purpose of this paper}

The purpose of this paper is to briefly outline the Glacier Dynamic database (GDdatabase), the fundamental principles behind it, and to give representative examples of different geological features belonging to the GDdatabase. We also briefly provide examples of site-specific mapping and on how the stored information can be applied in understanding the dynamics of ice stream lobes during glaciation. It must be emphasized that mapping of paleo-ice stream beds in the FIS is still in its infancy and that there are subglacial landforms whose precise origins and glaciological significance are far from clear. 


\section{Glacial terrain mapping}

Glacially derived sediments and landforms are inherently complex to classify and map and glacial geologists often simplify this process by employing a 'land system approach'; the terms 'depositional system' or 'facies model' are essentially synonymous. The fundamental assumption employed here is that surface landforms are genetically related - if depositional to their formation - with their internal sediments since they accumulated coevally during the same depositional event, e.g. during the closing stages of a single glacial cycle such as the Late Weichselian deglaciation at which the FIS formed and retreated over Finland approximately between 24000-10.500 cal yr. BP (Johansson et al., 2011). The land system concept has proved very useful as an organizing framework for fundamental mapping projects and geo-engineering, mineral exploration and hydrogeological assessments.

A number of glacial land systems are now recognized, the most recent being the ice stream land system', emphasizing the presence of highly elongate ridges (MSGLs) and lateral shear margin moraines (see Benn \& Evans, 2010; Ross et al., 2009, 2011; Evans et al., 2008, 2014; Ottesen et al., 2016; Eyles \& Doughty, 2016). This and the closely related drumlinized 'subglacial land system' consists of drumlinized terrain underlain by subglacially deposited till reflecting the assumption that drumlins are depositional bedforms that grow upwards by localized bed deformation and till deposition (Eyles, 1983; Eyles \& Eyles, 2010; Stokes et al., 2013; Spagnolo et al., 2016, Möller \& Dowling, 2016) such that surface landforms and internal sediments, are genetically related. Similarly, areas of hummocky moraine topography (the 'supraglacial land system'), which might rest on a subglacial land system, are viewed as the expression of underlying, often complexly-structured icecontact deposits resulting from the complex downwasting of an ice margin buried under supraglacial debris.
A land system approach has proven very useful in glacial geological studies for simplifying and integrating complex glacial systems (see Benn \& Evans (2010) for a comprehensive review, Evans et al. $(2008,2014)$ for examples from western North America or Alexanderson et al. (2001) for examples from arctic Siberia). However, despite its great utility, the fundamental assumptions underpinning the method are not always appropriate, especially in those areas of multiple glaciations or multiple events during a single glacial cycle, such as where older glacial deposits and/or landforms are preserved or have been partially reworked (cf. Lunkka et al., 2016). It is not employed here to map subglacial landscapes and sediments given recent arguments that drumlins and megaflutings (are here synonymous with MSGLs) are primarily erosional in origin cut across underlying materials that can include both sediment and rock (see Möller \& Dowling, 2015; Eyles et al., 2016; Krabbendam et al., 2016 and refs therein). In this sense many glacial landforms are palimpsest features resulting from reshaping of older materials (Benn \& Evans, 1998; see page 535). In cases such as this, the subglacial bed and the bedforms on its surface (e.g. drumlins, megaflutings) represent a major glaciallystreamlined unconformity cut across geneticallyunrelated sediments (and/or rock). In view of this we simply employ the term 'terrain' and recognize 'paleo-ice stream terrains' left by fast-flowing corridors within the last ice sheet to have covered Finland. In this way sediments and landforms are integrated together and linked to the history of ice sheet dynamics.

\section{Methodology and GD database}

For mapping glacial deposits, a LiDAR based DEM with primarily Multi-Directional Oblique Weighted (MDOW) hill-shade was used, which allows exceptional visual perception of the surface form of entire landscapes and individual landforms. 
Most of the Kuusamo Ice stream Lobe and about $70 \%$ from the Finnish Lake District Ice stream Lobe (FLDL) area were interpreted with different kinds of hillshade and DEM enhancement options, on which were used ArcGIS 10.4.1 for Desktop Image Analysis gradient filters (see ArcGIS 10.4.1; Help documentation; Gonzalez \& Wintz, 1987).

Convolution filters were applied to LiDAR and DEM 10 m data by $3 \times 3$ raster cell kernel, which calculates on different directional gradient to DEM data in 45 degree increments. Gradient filters are types of convolution filters, which are used in image analysis to edge detection (http://desktop.arcgis. com/en/arcmap/10.4/manage-data/raster-andimages/convolution-function.htm). These filtered layers are in use during the mapping process in some areas to help interpretation. On ArcGIS Image analysis, using those gradient filters in grayscale, the result raster will be hillshaded from calculated convolution direction. DEM data was also calculated by Laplacian 5 by 5 convolution kernel function to emphasize landforms. Combination of piled filter rasters emphasizes landforms from LiDAR DEMs regardless of orientation from different directions.

In this project individual landforms are commonly digitized by hand from LiDAR DEMs using ArcGIS editing tools. During the project some automatic or semi-automatic customized algorithms of ArcGIS and eCognition software for MGSL mapping were also tested. However, the result of the latter showed to be uncertain and too inaccurate for the intended use of the GDdatabase. It was noted that digitizing by hand was necessary for detailed mapping results. Landforms are preferably digitized in-line and closed areas are then labelled with points. In the end these are processed to polygons representing each class of deposit or bedform. However, some of the classes remain in line shape, for example glacial lineations including drumlins and flutings.

The new GDdatabase is created as a file geodatabase in Esri's ArcGIS platform and it consists of multiple datasets, feature classes and domain lists. The GDdatabase structure and classification of the deposits and landforms have been and are still subject to change during the ongoing development process. The up to date comprehensive classification chart of the GDdatabase is available as a supplementary data (Electronic Appendix B). The classification is thematic but also represents a simple technical composition (http://desktop.arcgis.com/en/ $\operatorname{arcmap} / 10.4 / \mathrm{manage-data} / g e o d a t a b a s e s / t y p e s-o f-$ geodatabases.htm).

In revising pre-existing data pertaining to previously mapped Quaternary deposits and aggregate deposits, we have also applied a grid and raster painting editor developed by Aris B.V. (http://www.aris.nl/gridrastereditor_arcmap). In this method polygons are transferred to raster in order to rapidly paint new borders and correct possible inaccuracies of different classes to preexisting map shapes. This process is somewhat quicker than digitizing vertex by vertex in vectorised features. Both methods are in use but most of the new data is processed as vectorised data, polygons, lines and points.

\subsection{Landform and deposit classes}

The GDdatabase contains a large set of landforms and various sub classes as well as deposit types, all of which are identified on LiDAR MDOW DEM maps, together with explanations (see Electronic Appendices). This approach provides a powerful analytical tool for studying and recognizing different geological and geomorphological landform types across Finland indexed to the Preliminary Ice stream lobes Map of Finland (PIMF) (Fig. 1 and Electronic Appendix A). These classes of the GDdatabase are shown in Electronic Appendices B-E. They range from meltwater-deposited landforms (eskers, sandur plains, deltas, kames) and till-dominated complexes with secondary information as to the location of where they accumulated, e.g. as interlobate eskers or as ice marginal moraines (e.g., Fig. 2). 


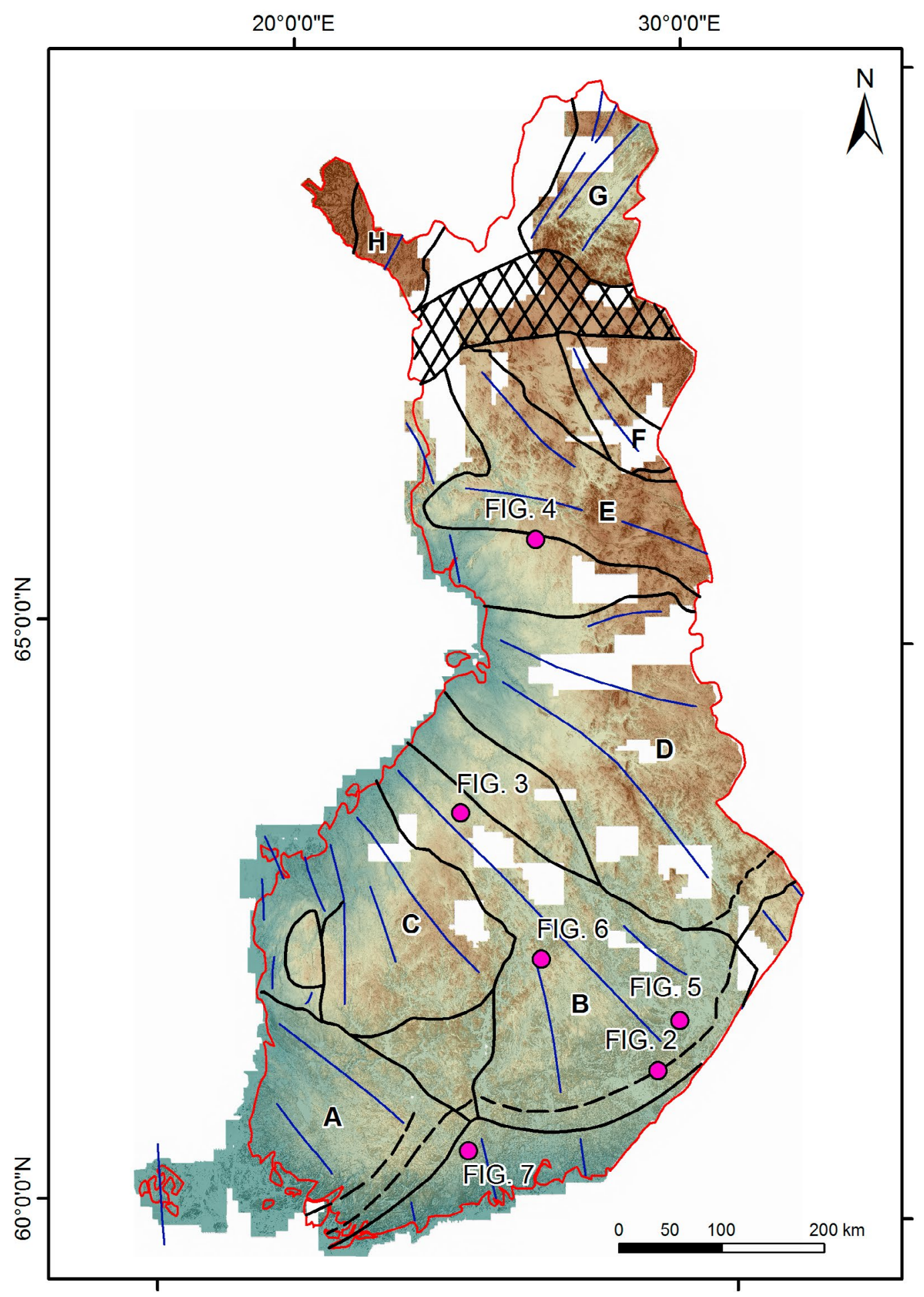

Figure 1. LiDAR-based Preliminary Ice stream lobes Map of Finland (PIMF). Main ice stream lobes (A. Baltic, B. Lake district, C. West, D. North Karelian/Oulu, E. Kuusamo, F. Salla, G. Inari and H. Enontekiö) of Finland resting on LiDAR DEM (6/2017 coverage). Ice lobe margins (black), ice divide zone at North (raster), main flow lines (blue) and figure locations are indicated. 


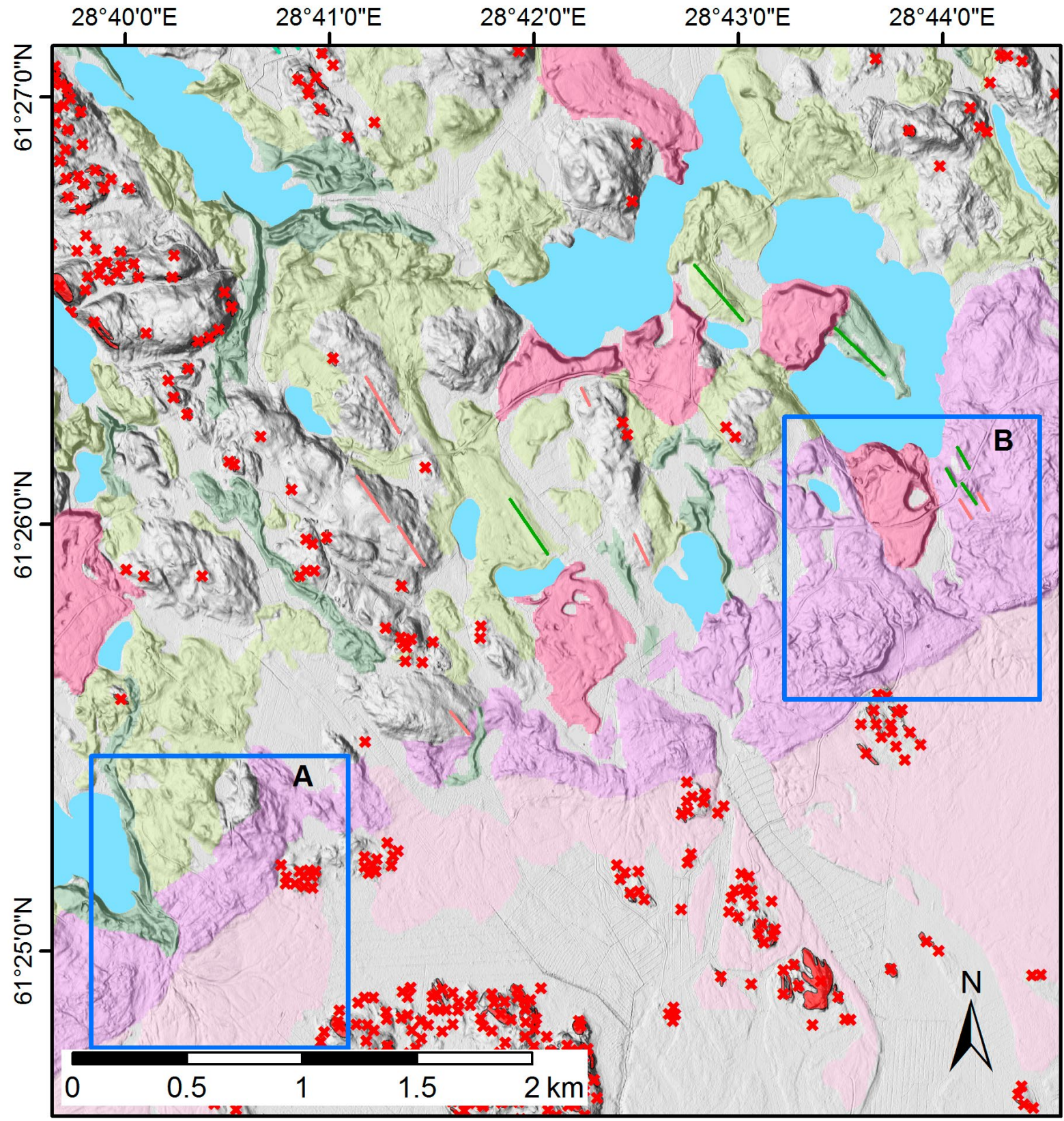

Figure 2. LiDAR DEM and landform interpretation and classification of a complex ice marginal deposit near the village of Reinikkala in southeastern Finland north of the Salpausselkä II moraine. Two inset rectangles (2A and 2B) show detailed landforms within the complex. Eskers (green), deltas (red) and an outwash plain (light pink) with braided channels, proximal ice-contact glaciofluvial sand and gravels (yellow) and a large ice marginal moraine (purple) are geneticallyrelated and formed along the retreating ice margin. Ice flow directions are recorded by drumlins (green lines) and flutings (pinklines). 


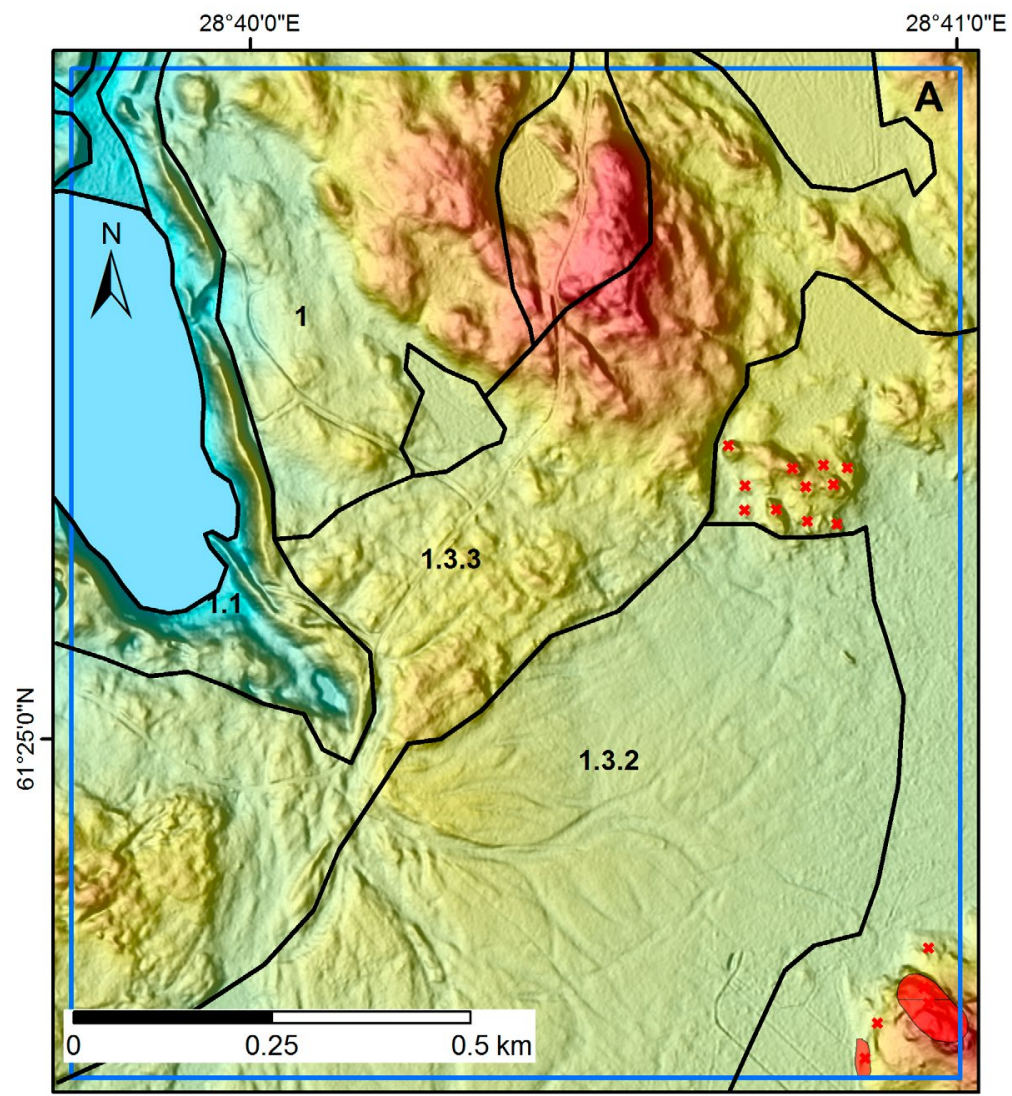

Figure 2, inset A. A glaciofluvial complex (1), an esker system (1.1), an outwash plain (1.3.2) with braided channels, and proximal ice-contact glaciofluvial sand and gravel (1.3.3) are formed at the Salpausselkä II.

Figure 2, inset B. A glaciofluvial delta (1.3.1), an outwash plain (1.3.2) with braided channels, an ice-contact glaciofluvial deposit (1.3.3), and a large ice marginal dump moraine complex (4.1.1) represent the position of the ice margin during the Salpausselkä II stage. Drumlins (green) and flutings (pink) indicate the ice flow direction toward the ice stream terminus.

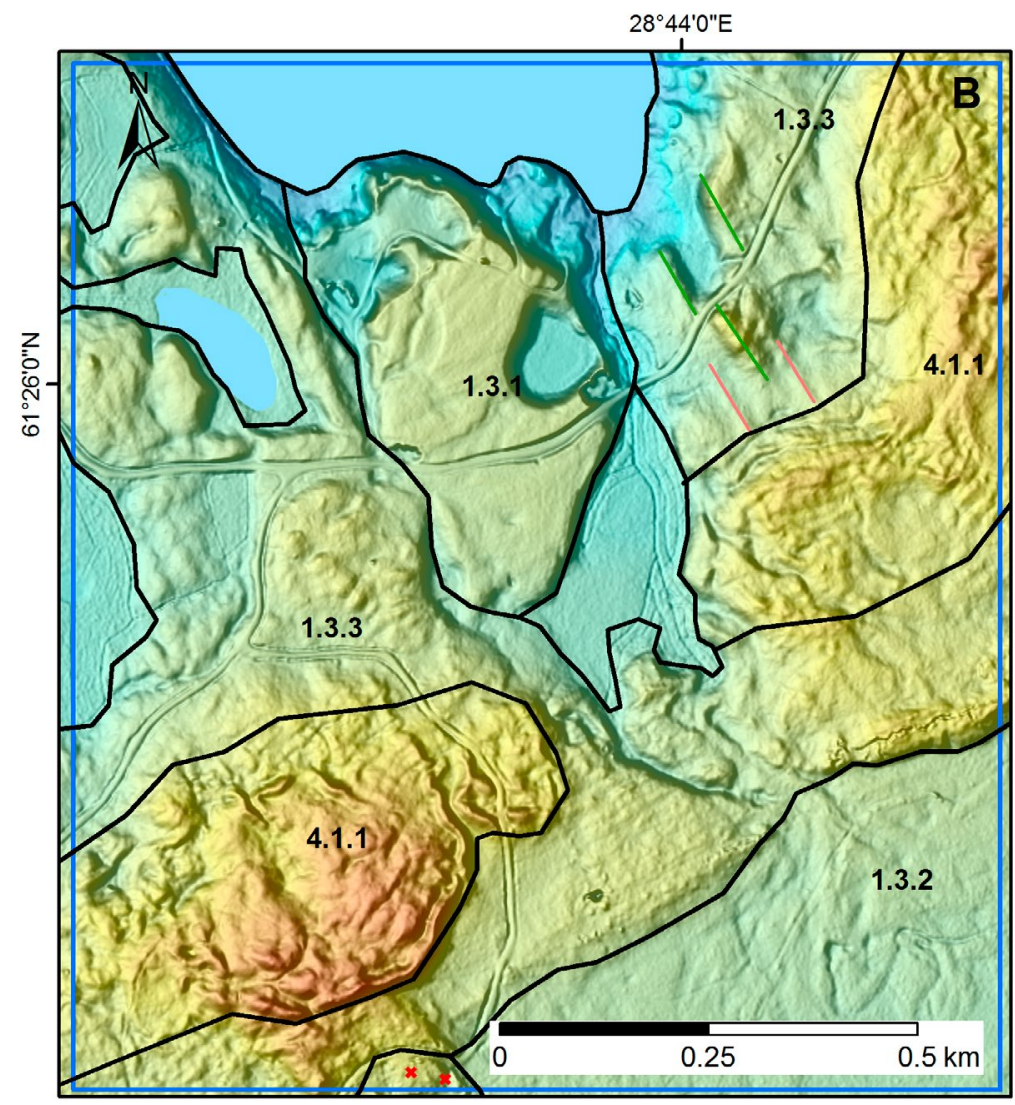


A wide variety of moraine ridge types are incorporated into the GDdatabase, ranging from recessional moraine ridges and De Geer moraines (Figs. 2 and 7; see also Electronic Appendices D:27, E:33, E:36, E:37, E:38 and E:39) to large push moraine complexes recording significant still stands of an ice margin (Fig. 2) see also Electronic Appendices C:15, D:23 and D:28), to areas of ribbed moraine forms typical of ice centres with sluggish or stagnant ice flows. Ribbed moraines are divided into three main morphological sub-types: hummocky ribbed moraine, Rogen moraine and minor ribbed moraine following the classifications of Hättestrand (1997) and Sarala (2003, 2006) (Figs. 3 and 4; see also ribbed moraine in the Electronic Appendices C:4, C:5, C:6, C:7 and
C:9). Furthermore, occasionally it is possible to recognize a fourth type of the ribbed moraines, "arcuate-shaped" forms composed of diamicton which are more closely related to subglacial hummocky moraines and meltstreams features (Fig. 3; see also Electronic Appendices C:8, C:9, $\mathrm{E}: 32$ and E:34). Understanding of these transverse moraine forms is not yet complete and awaits further subsurface data as to their composition; existing data identifies coarse-grained often bouldery cores indicative of limited distances of glacial transport (e.g., Mäkinen et al., 2017). Large areas of hummocky moraine record supraglacial deposition of diamicts as well as sorted glaciofluvial or glaciolacustrine sediment over stagnant ice. These sediments are ultimately redeposited during

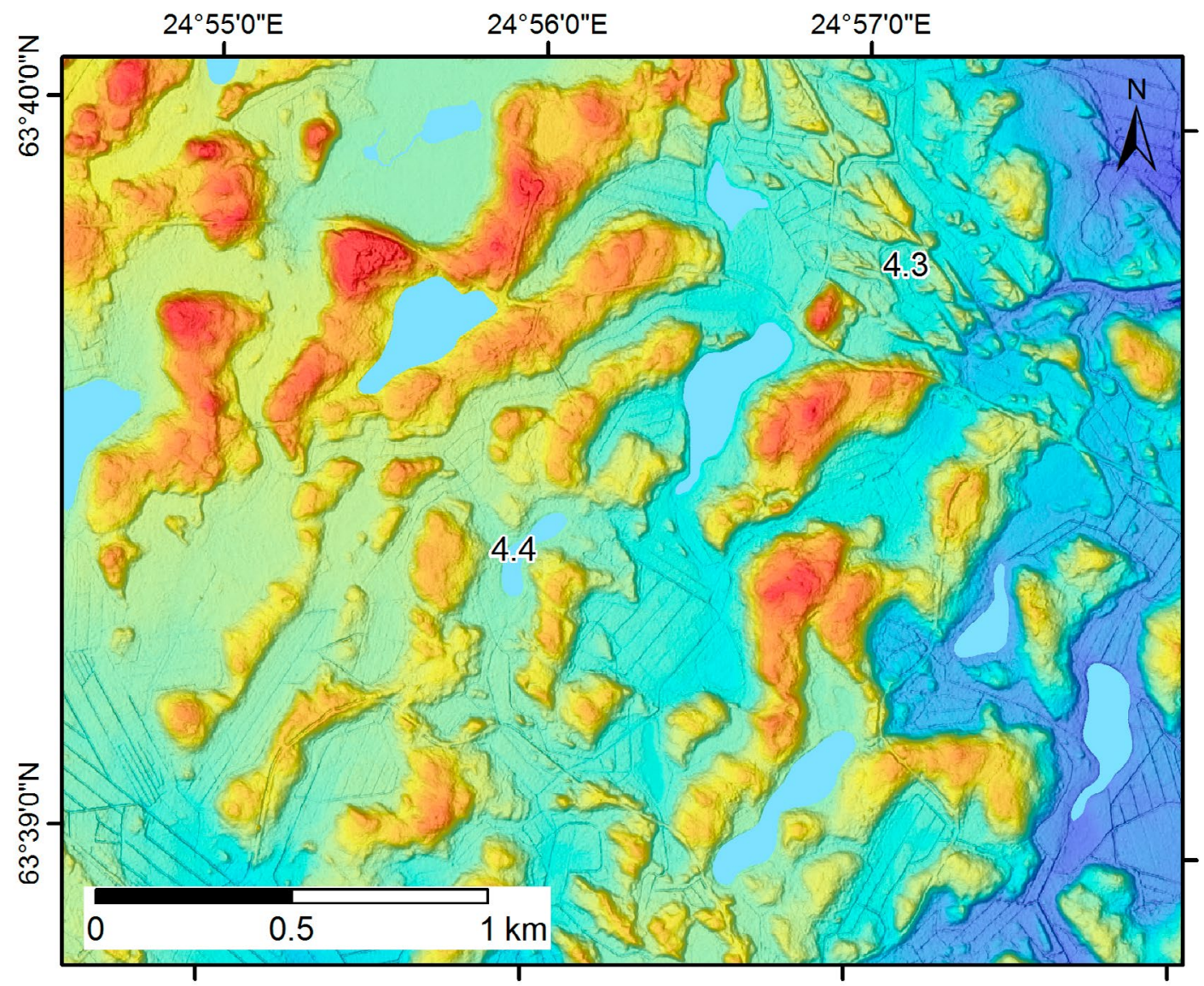

Figure 3. Ribbed moraine (code 4.4) deposited under sluggish ice flow velocities in Nivala-Haapajärvi in central Finland typical of inter ice stream areas and onset zones. Poorly understand arcuate-shaped hummocky ribbed moraines (code 4.3) may record some type of mass flow deposit. Fast ice flow and ice streaming is recorded by MSGLS (Fig. 5). 


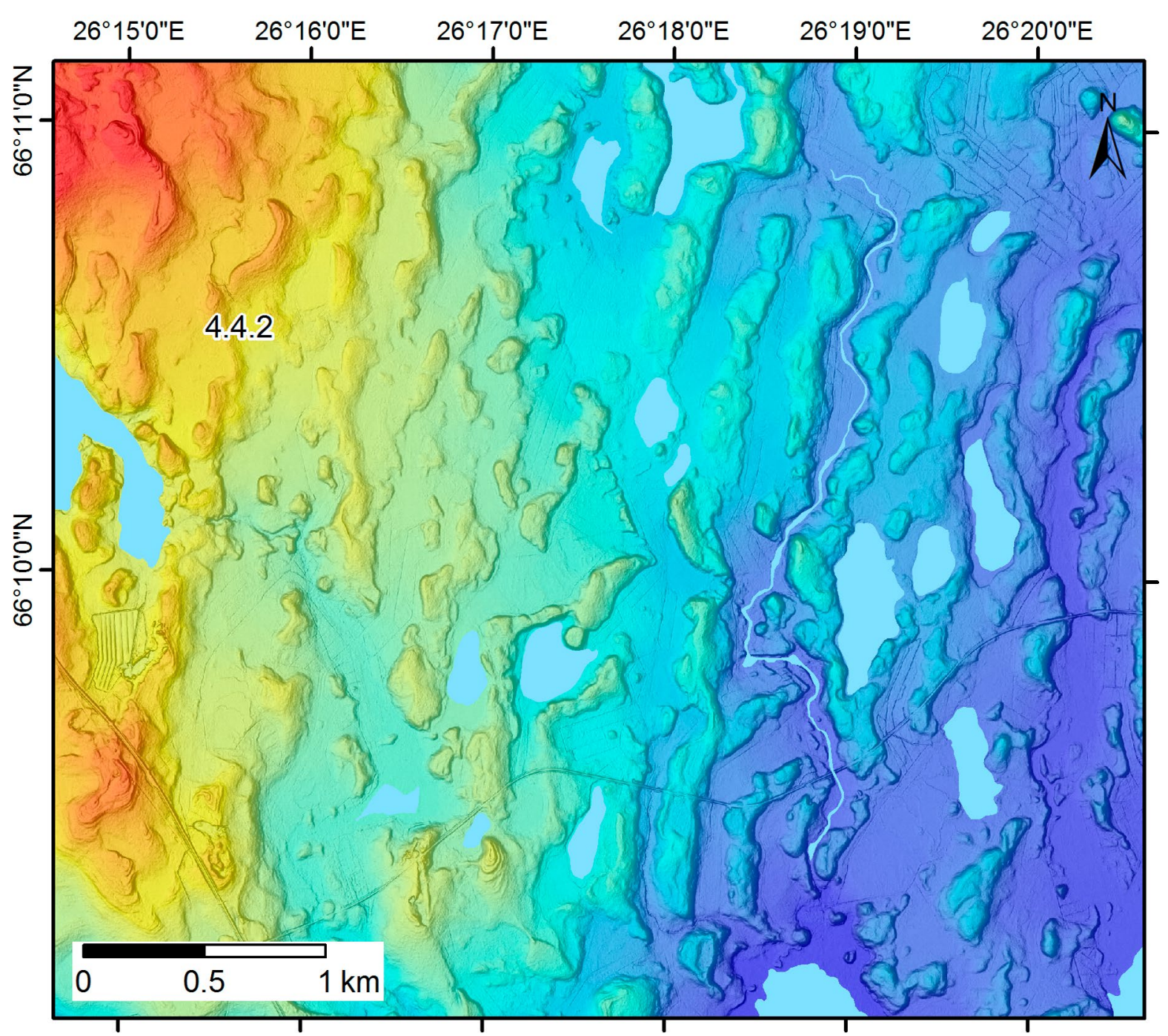

Figure 4. Well-developed ribbed (Rogen) moraine (code 4.4.2) typical of cold-based ice and sluggish ice flow velocities, in the Portimojärvi region about $20 \mathrm{~km}$ NW from the town of Ranua.

ice down-wasting, forming a hummocky or 'kettled' surface.

Other identified features are littoral deposits formed along former coasts. In addition, the database also relates to databases with drilling, ground penetrating radar, reflection seismic and downhole seismic and other geophysical data identifying the presence of buried pre-Late Weichselian deposits. Of special significance are glacially streamlined terrain composed of drumlins and megaflutings (Figs. 5 and 6), crag and tails and pre-crags (Fig. 5; see also Electronic Appendices
C:1-3, C:8-13, D:16-D:22, D:24, D:26, D:29, E:31-32 and E:38). These not only identify flow direction at formation but also identify the trunks of ice streams and their lateral margins with slowerflowing or stagnant ice (Fig. 1 and Electronic Appendix A). Many of these sets suggest abrupt changes in ice flow direction, often expressed a superposed crossing striations and streamlined bedforms. This is consistent with 'ice flow switching' during deglaciation (see Electronic Appendices C:2, C:13 and D:29). 


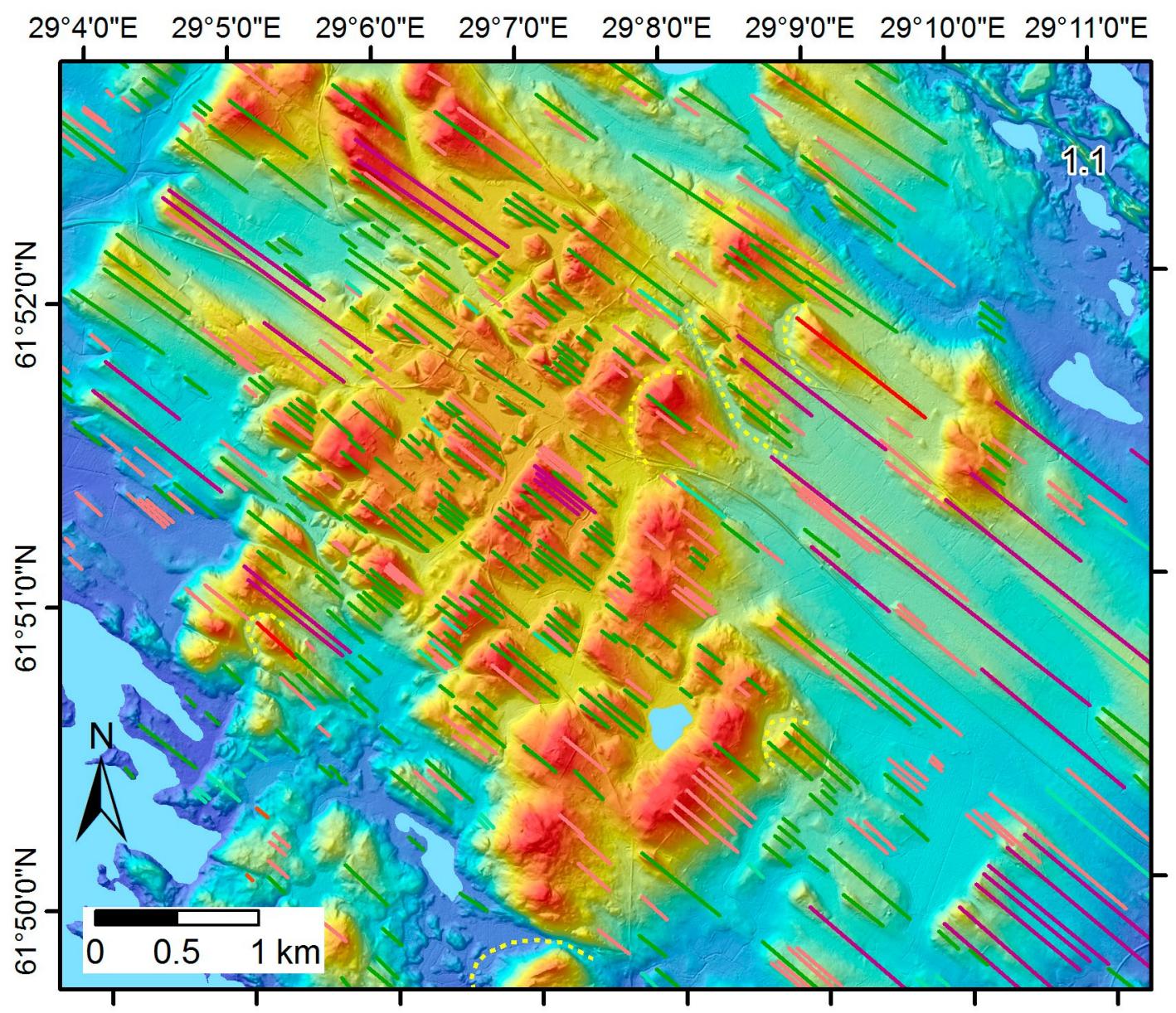

Figure 5. Large numbers of crag and tail glacier lineations suggest fast flowing ice masses crossing relatively thin sediment cover resting on the Fennoscandian shield at Kuuttilanmäki, Savonlinna. This type of prevalent topography occurs in large areas across the middle and southern Finland. Flutings are indicated in pink lines, drumlins (green), megaflutings (purple), through valleys and crescent troughs (yellow).

So-called 'pre-crag' deposits are common features in southwestern Finland. A typical precrag forms at divergent ice flow around an emergent bedrock high; subglacially deforming debris flow around bedrock preserves pre-existing sediment (such as till) on the upstream (stoss) side of the obstruction (e.g., Haavisto-Hyvärinen et al., 1989). Morphologically they are the mirror-image of crag and tails features where pre-existing sediment is left in lee of a bedrock knob or where sediment was deposited in subglacial lee-side cavities (see Electronic Appendix E:38).
Much drumlinized terrain in Finland is cut across thick antecedent older deposits leaving as large drumlinized 'uplands' (Gluckert, 1973; Möller \& Dowling, 2015; Möller \& Murray, 2015) (see Electronic Appendices D:19-21 and D:26) and what have been termed 'megadrumlins' (Eyles et al., 2016). These have conjoined drumlins on their surface reflecting limited subglacial erosion and dissection of pre-existing sediment. Drumlins are differentiated from megaflutings by conventional analysis of their elongation ratios (ER), i.e., length divided by width; megaflutings usually have ERs 


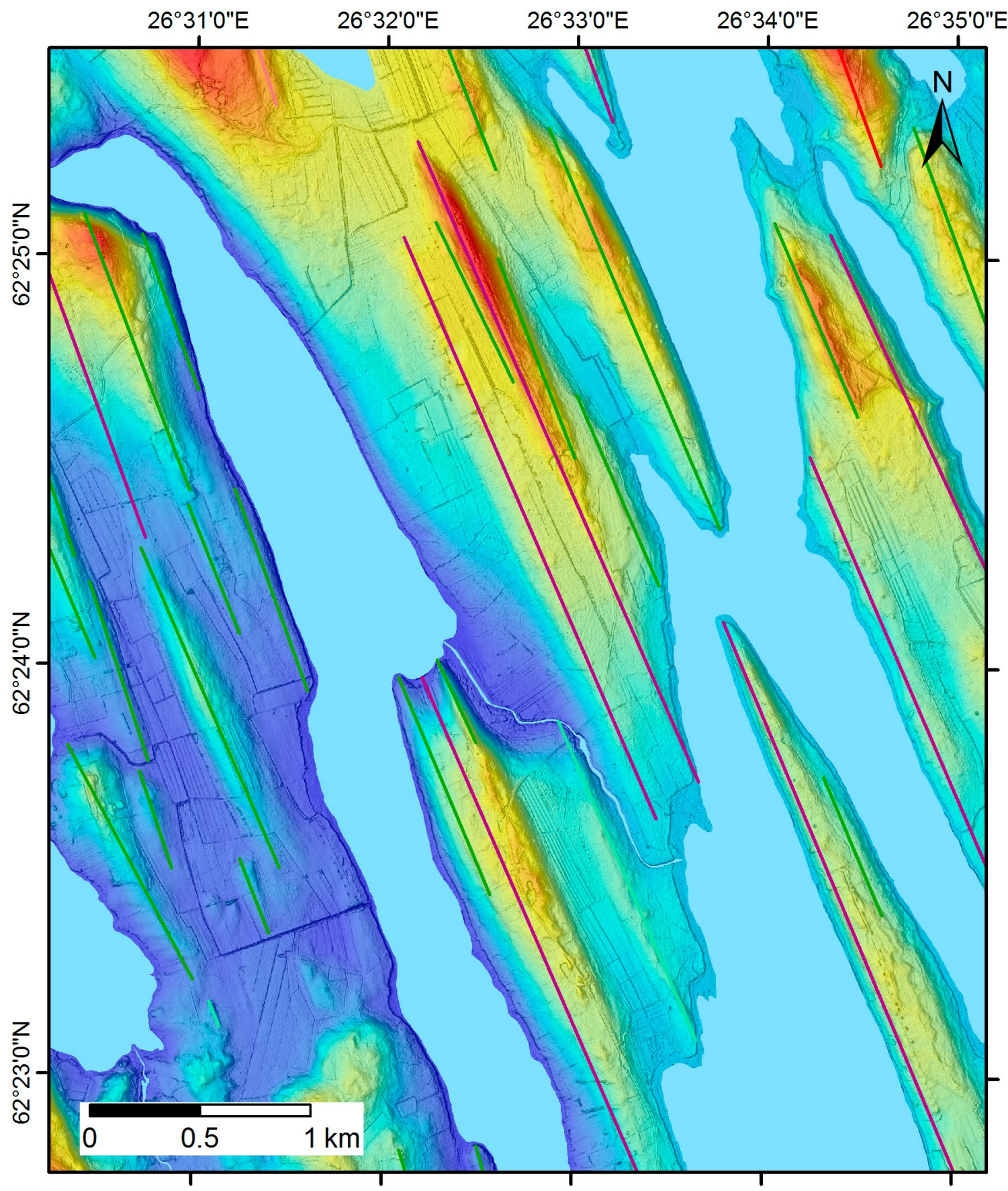

Figure 6. Megascale glacial lineations in the vicinity of Hankasalmi in the Suolivesi region typical of the subglaciallystreamlined bed of the Finnish Lake District Ice stream Lobe that crossed central Finland (Fig. 8). For symbols see Fig. 5 and Electronic Appendices C-E. 
larger than 7:1 and sometimes as much as 40:1 (Figs. 5 and 6). Typically, these bedforms consist of a thin $(>1 \mathrm{~m})$ carapace of till resting erosively on older sediment, which suggests an erosional origin at which the ice-bed interface has been smoothed by erosional streamlining of larger irregularities (i.e. drumlins), enabling faster ice flow over a lower friction surface (e.g., Eyles et al., 2016; Möller and Dowling, 2016). Some glacially streamlined bedforms are cut into rock of various types, in their dimensions ranging from roche moutonnées to drumlins and megaflutings scale (rock drumlins) (Krabbendam et al., 2016).

An ice stream terrain model is a very useful integrator of a diverse range of landforms and sediments associated with fast (and sluggish) flowing ice. As such it provides a very useful regional mapping framework and this is one of the prime objectives underlying development of the GDdatabase. A comprehensive inventory of landforms and deposits recording paleo-ice streams is now possible for the Finnish sector of the last FIS. While this is beyond the scope of the present study we give some provisional comments and illustrations below.

\section{Ice stream lobes in Finland and deglaciation dynamics}

Currently, the GDdatabase includes more than 280000 individual glacial geomorphological features from four different ice stream lobes across Finland with a focus on the Inari, Kuusamo, Northern Karelia/Oulu and Finnish Lake District ice stream lobes for which there has been a systematic mapping effort (see Electronic Appendix A). Some of these landforms are illustrated elsewhere in this volume with examples of glacially streamlined terrain from the Kuusamo Ice stream Lobe (Sarala \& Räisänen, this volume; also Putkinen \& Lunkka, 2008) and the North Karelian/Oulu Ice stream Lobe (Nikarmaa et al., this volume; also Putkinen \& Lunkka, 2008). What follows below is focussed on examples drawn from the Finnish Lake District Ice Lobe (FLDL); however it must be emphasized that other ice stream lobes across the Fennoscandian Shield left similar terrain systems. Such typically consist of corridors with a distinct downflow 'morphosequences' composed of upstream ribbed moraine of Rogen type formed beneath slowly moving to close to stagnant ice near ice divides (Fig. 4), transforming downflow into streamlined terrain (drumlins) (e.g. Sarala, 2006; 2015), representing enhanced ice flow velocities $\left(-100 \mathrm{~m} \mathrm{yr}^{-1}\right)$, that in turn transforms into highly elongate megaflutings recording even faster ice flow (velocities above $400 \mathrm{~m} \mathrm{yr}^{-1}$ and larger ( $3 \mathrm{~km} \mathrm{yr}^{-1}$ ) based on the behaviour of modern ice streams. Such morphosequence were first noted by Lundqvist (1969) and Aario (1977) but it is now possible to relate such bedform transitions to likely ice flow velocities as part of a glaciodynamic bedform hierarchy similar to that developed by fluvial sedimentologists for bedforms produced by unidirectional currents (e.g. Bridge, 2006). Downstream reductions in ice flow velocities are also expressed as transitions from megaflutings back to drumlins; former ice margin positions are recorded by large morainal complexes (Fig. 2), reflecting the delivery of much subglacial debris to the margin by advection of 'soft' deforming till (e.g. Eyles et al., 2011). Such debris is partially reworked subglacially by canalized meltwater streams and left as esker-fan complexes or much larger sandur plains during ice retreat (Fig. 2) (see Boulton et al., 2001; Putkinen \& Lunkka, 2008; Eyles et al., 2015; Ojala et al., 2016). Significant areas of dissected meltwater-deposited sediment terrain underlain by glaciotectonically-deformed and partially collapsed outwash interbedded with diamict facies deposited by mass flow at subaqueous-terminating ice margins at water depths of $50 \mathrm{~m}$ or more. These relatively high standing landforms cross Southern Finland and contain significant groundwater resources that also recharge underlying and immediately surrounding areas of fractured crystalline rock.

The bed of the former FLDL is depicted by many examples in the Electronic Appendix D figures 17-22 with megaflutings and other 


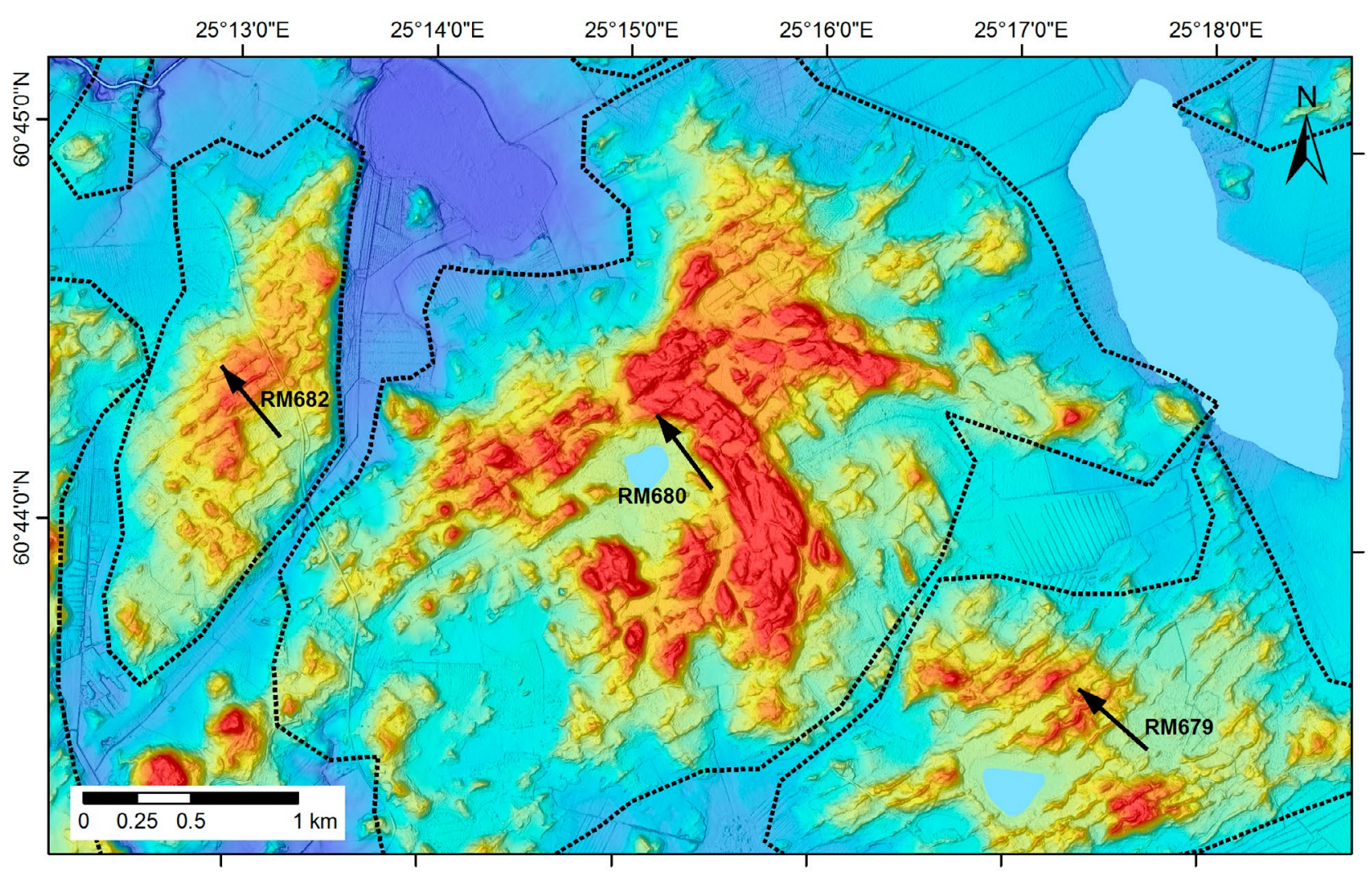

Figure 7. De Geer moraine fields (DGM \#RM679, RM680, RM682) of the Sälinkää-Suojärvi-Sulkava areas of Mäntsälä in southcentral Finland. Direction of deglaciation is shown by black arrows.

genetically-related subglacial bedforms such as precrags, drumlins (both rock drumlins and sedimentcored such) together with ribbed moraine when approaching adjacent to the ice flow corridors. An excellent example of the higher resolving power of LiDAR is provided by analysis of De Geer moraines (DGMs) formed during ice retreat (Fig. 7) at subaqueous margins.

LiDAR data are also generating new information regarding subglacial landforms whose origin is not yet fully understood. For example, topographically-irregular bodies of sediment that have been dissected by numerous poorly-integrated channels appear to have accumulated at the lateral margins of under fast flowing ice (Electronic Appendix E:34 and Mäkinen et al., 2017). These may represent poorly integrated subglacial drainage systems. Some have a distinctly beaded form likely recording successive retreat positions of the ice margin in water akin to the formation of beaded eskers. In this regard, large esker networks formed across the central southern Finland during the last deglaciation. These are largely parallel to glacier (FLDL) flow lines indicated by drumlins and megaflutings, suggesting there was no major ice stream re-organization in the FLDL during retreat from the Salpausselkä end moraine zone (Fig. 8). 


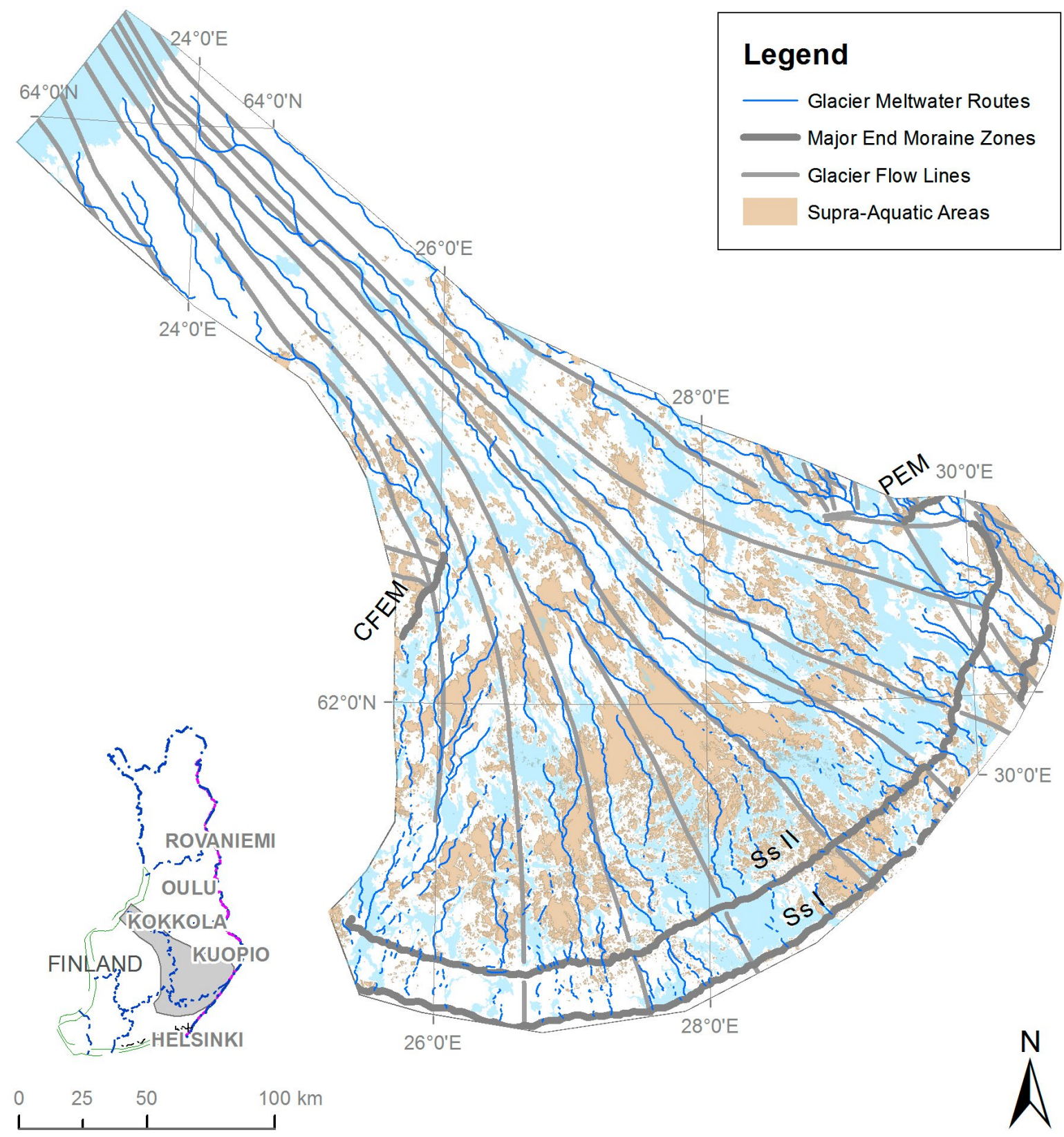

Figure 8. Preliminary map of the former extent of the $500 \mathrm{~km}$ long Finnish Lake District Ice stream Lobe in central Finland showing main glacier flow lines, principal routes of meltwaters and relatively high standing 'supra aquatic' areas. Margins of the ice stream are defined by the Central Finland End Moraine (CFEM), the Salpausselkä End Moraines (SS I, SS II) and the Pielisjärvi End Moraine (PEM). Fast ice flow may have been sustained by extensive marginal and submarginal bodies. Regional LiDAR mapping by GTK allows integration of diverse, widespread but genetically related landforms and sediments within distinct mappable 'ice stream terrains.' 


\section{Discussion}

As related above, clearest advantage of the GDdatabase, and the glacial terrain mapping approach on which it is based, is that it integrates a wide variety of landforms and sediments that hitherto were mapped and treated quite separately. With the new approach genetically-related elements can be linked within a simple 'paleo-ice stream' terrain model. Their distribution of mapped glacial landform across Finland fundamentally reflects the flow and subsequent demise of ice streams and their associated lobate margins across the Fennoscandian Shield (Electronic Appendix A). This conceptual framework integrates data across large areas that have been treated separately on formerly produced individual Quaternary map areas at the 1:20000, 1:50000 or even 1:100000 scale. Traditional mapping technique is also relatively expensive and time consuming, compared to LiDAR-based mapping. Broad scale LiDAR-based terrain mapping is rapid and inexpensive and data can be used to recreate regional-scale glacier dynamics reconstructions for the entire Finnish sector of the FIS and by that give the 'bigger picture' of ice-lobe dynamics. Another benefit of the LiDAR mapping is that it reveals cross-cutting relations between terrain elements as ribbed moraine, drumlins and megaflutings and older sediments/landforms from previous ice flow phases. This is critically important to mineral exploration projects where; much prior work has simply assumed that underlying sediments (and any mineralized 'float' present in the sediment) records the same phase (and direction) of ice flow as expressed by surface landforms. Detailed examination of these older deposits is now required, together with re-evaluation of their glaciological setting for new second-generation mineral exploration initiatives. In a glaciodynamic perspective such antecedent sediment bodies acted as a 'soft bed' and greatly reduced overall bed roughness at the ice-bed interface; they were also a source for producing till.

In conclusion, the GDdatabase being developed by Geological Survey of Finland represents a highly cost effective methodology not only for understanding the glacial history and dynamics of the Finnish sector of the last FIS, but also for rapidly conveying critical applied information with respect to glacial landscapes, topography and sediments. This knowledge is needed for a variety of projects involving geoengineering, urban planning, water resource protection and management, together with mineral exploration projects and prospecting for aggregate supplies.

\section{Acknowledgements}

This paper is the result of a strong teamwork between various GTK divisions. We would like to thank Directors Jarmo Kohonen, Olli Breilin and Petri Lintinen and the mapping development team of Tapio Väänänen, Jukka Räisänen, Tilda Rantataro, Satu Putkinen, Antti Ojala, JukkaPekka Palmu, Jouko Saarelainen, Niina Ahtonen, Pertti Sarala, Hannu Rönty, Arto Kiiskinen, Tom Rauhaniemi, Jukka Ojalainen, Peter Johansson, Tapani Tervo, Timo Huttunen, Niina Ahtonen, and Kirsti Keskisaari. We also thank P. Möller and C. Ó. Cofaigh for their very helpful reviews of an earlier version of this paper.

\section{Supplementary data}

Electronic Appendices A-E for this article are available via Bulletin of the Geological Society of Finland web page. 


\section{References}

Aario, R., 1977. Associations of flutings, drumlins, hummocks and transverse ridges. GeoJournal 1:6, 65-72. https://doi.org/10.1007/BF00195540

Alexanderson, H., Hjort, C., Möller P., Antonov, O. \& Pavlov, M., 2001. The North Taymyr ice-marginal zone, Arctic Siberia - a preliminary overview and dating. Global and Planetary Change 31, 427-445. https://doi.org/10.1016/S0921-8181(01)00133-3

Benn, D.I., \& Evans, D.J.A., 1998. Glaciers and Glaciation. Arnold, London, $734 \mathrm{p}$.

Benn, D.I., \& Evans, D.J.A., 2010. Glaciers and Glaciation, $2^{\text {nd }}$ Edition. Routledge, London and New York, 802 p. https://doi.org/10.4324/9780203785010

Boulton, G.S., Dongelmans, P., Punkari, M. \& Broadgate, M., 2001. Palaeoglaciology of an ice sheet through a glacial cycle: the European ice sheet through the Weichselian. Quaternary Science Reviews 20, 591-625. https://doi.org/10.1016/S0277-3791(00)00160-8

Bouvier, V., Johnson, M. \& Påsse, T., 2015. Distribution, genesis, and annual-origin of De Geer moraines in Sweden: insights revealed by LiDAR. GFF 137, 119-333. https://doi.org/10.1080/11035897.2015.1089933

Bridge, J. S., 2006. Fluvial Facies Models: Recent Developments. In: Posamentier, H.W. \& Walker R.G. (eds.), Facies models revised. Society for Sedimentary Geology, Special Publications 84, pp. 85-170. https://doi.org/10.2110/pec.06.84.0085

Dowling, T.P.F, Möller, P. \& Spagnolo, M., 2016. Rapid subglacial streamlined bedform formation at a calving bay margin. Journal of Quaternary Science 31, 879-892. https://doi.org/10.1002/jqs.2912

Glückert, G., 1973. Two large drumlin fields in central Finland. Fennia 1201-37.

Greenwood, S.L., Clason, C.C., Mikko, H., Nyberg, J., Peterson, G. \& Smith, C.A., 2015. Integrated use of LiDAR and multibeam bathymetry reveals onset of ice streaming in the northern Bothnian Sea. GFF 137, 284292.

https://doi.org/10.1080/11035897.2015.1055513

Gonzalez, R.C. \& Wintz, P., 1987. Digital Image Processing. Addison-Wesley, Reading, Massachusetts, $2^{\text {nd }}$ edition, 503 p.

Eilertsen, R.S., Corner, S.D. \& Hansen, L., 2015. Using LiDAR data to characterize and distinguish among different types of raised terraces in a fjord-valley setting. GFF 137, 353-361. https://doi.org/10.1080/11035897.2015.1111409

Evans, D.J.A., Clark, C.D. \& Rea, B.R., 2008. Landform and sediment imprints of fast glacier flow in the southwest Laurentide Ice Sheet. Journal of Quaternary Science 23, 249-272.

https://doi.org/10.1002/jqs.1141
Evans, D.J.A., Young, N.J.P. \& Cofaigh, C.Ó., 2014. Glacial geomorphology of terrestrial-terminating fast flow lobes/ ice stream margins in the southwest Laurentide Ice Sheet. Geomorphology 204, 86-113.

https://doi.org/10.1016/j.geomorph.2013.07.031

Eyles, N., 1983. Modern Icelandic glaciers as depositional models for 'hummocky moraine' in the Scottish Highlands. In: Eversen, E.B. et al. (eds.), Tills and related deposits. Balkema, Rotterdam, pp. 47-59.

Eyles, N., Boyce, J. \& Putkinen, N. 2015., Neoglacial (<3000 years) till and flutes at Saskatchewan Glacier, Canadian Rocky Mountains, formed by subglacial deformation of a soft bed. Sedimentology 62, 182-203. https://doi.org/10.1111/sed.12145

Eyles, N. \& Doughty, M., 2016. Glacially-streamlined hard and soft beds of the paleo-Ontario ice stream in Southern Ontario and New York state. Sedimentary geology 338, 1, 51-71. https://doi.org/10.1016/j.sedgeo.2016.01.019

Eyles, C.H. \& Eyles, N., 2010 Glacial Facies. In: James N.P. \& Dalrymple G. (eds.), Facies Models 4. Geological Association of Canada 6, pp. 73-104.

Eyles, N., Eyles, C.H. \& Menzies, J., 2011. End moraine construction by submarginal incremental till deposition below the Laurentide Ice Sheet, Southern Ontario, Canada. Boreas 40, 92-104. https://doi.org/10.1111/j.1502-3885.2010.00171.x

Eyles, N., Putkinen, N., Sookhan, S. \& Arbelaez-Moreno, L., 2016. Erosional origin of drumlins and megaridges. Sedimentary Geology 338, 2-23. https://doi.org/10.1016/j.sedgeo.2016.01.006

Haavisto-Hyvärinen M., Kielosto S. \& Niemelä J., 1989. Precrags and drumlin fields in Finland. Sedimentary geology 62, 337-348. https://doi.org/10.1016/0037-0738(89)90123-1

Hättestrand, C., 1997. Ribbed moraines in Sweden - distribution pattern and paleoglaciological implications. Sedimentary Geology 111, 41-56. https://doi.org/10.1016/S0037-0738(97)00005-5

Johansson, P., Lunkka, J. P. \& Sarala, P., 2011. The glaciation of Finland. Quaternary glaciations-extent and chronology: a closer look. Developments in Quaternary Science 15, 105-116.

https://doi.org/10.1016/B978-0-444-53447-7.00009-X

Johnson, M., Fredin, O., Ojala, A.E.K. \& Peterson, G., 2015. Unraveling Scandinavian geomorphology: The LiDAR revolution. GFF 137, 245-251. https://doi.org/10.1080/11035897.2015.1111410

Krabbendam, M., Eyles, N., Putkinen, N., Bradwell, T. \& Arbelaez-Moreno, L., 2016. Streamlined hard beds formed by palaeo-ice streams: A review. Sedimentary Geology 338, 1, 24-50. https://doi.org/10.1016/j.sedgeo.2015.12.007 
Lunkka, J. P., Lintinen, P., Nenonen, K., Huhta, P., 2016. Stratigraphy of the Koivusaarenneva exposure and its correlation across central Ostrobothnia, Finland. Bulletin of the Geological Society of Finland 88, 53-67. https://doi.org/10.17741/bgsf/88.2.001

Mikko, H., Smith, C.A., Lund, B., Ask, M.V.S. \& Munier, R., 2015. LiDAR-derived inventory of post-glacial fault scarps in Sweden. GFF 137, 334-338. https://doi.org/10.1080/11035897.2015.1036360

Mäkinen, J., Kajuutti, K., Palmu, J.-P., Ojala, A. \& Ahokangas, E., 2017. Triangular-shaped landforms reveal subglacial drainage routes in SW Finland. Quaternary Science Reviews 164, 37-53. https://doi.org/10.1016/j.quascirev.2017.03.024

Möller, P. \& Dowling, T.P.F., 2015. The importance of thermal boundary transitions on glacial geomorphology; mapping of ribbed/hummocky moraine and streamlined terrain from LiDAR, over Småland, South Sweden. GFF 137, 252-284. https://doi.org/10.1080/11035897.2015.1051736

Möller, P. \& Murray, A.S., 2015. Drumlinised glaciofluvial and glaciolacustrine sediments on the Småland peneplain, South Sweden - new evidence on the growth and decay history of the Fennoscandian Ice Sheets during MIS 3. Quaternary Science Reviews 122, 1-29.

https://doi.org/10.1016/j.quascirev.2015.04.025

Möller, P. \& Murray, A.S., 2015. The importance of thermal boundary transitions on glacial geomorphology; mapping of ribbed/hummocky moraine and streamlined terrain from LiDAR, over Småland, South Sweden. GFF 137, 252-283. https://doi.org/10.1080/11035897.2015.1051736

Möller, P. \& Dowling, T.P.F., 2016. Streamlined subglacial bedforms on the Närke plain, south-central Sweden - areal distribution, morphometrics, internal architecture and formation. Quaternary Science Reviews 146, 182215 . https://doi.org/10.1016/j.quascirev.2016.04.007

Nikarmaa, T., Lunkka, J.P. \& Putkinen, N., 2017. Factors affecting the dynamics of the North Karelian/Oulu Ice Lobe, Central Finland, during the last deglaciation - a LiDAR and DEM interpretation of subglacial lineation patterns. Bulletin of the Geological Society of Finland. This volume.

Ojala, A.E.K., 2016. Appearance of De Geer moraines in southern and western Finland - implications for reconstructing glacier retreat dynamics. Geomorphology 255, 16-25.

https://doi.org/10.1016/j.geomorph.2015.12.005

Ojala, A.E.K., Palmu, J.-P., Åberg, A., Åberg, S. \& Virkki, H., 2013. Development of an ancient shoreline database to reconstruct the Litorina Sea maximum extension and the highest shoreline of the Baltic Sea basin in Finland. Bulletin of the Geological Society of Finland 85, 127-144.
Ojala, A.E.K., Putkinen, N., Palmu, J.-P. \& Nenonen, K., 2015. Characterization of De Geer moraines in Finland based on LiDAR DEM Mapping. GFF 137, 304-318. https://doi.org/10.1080/11035897.2015.1050449

Ottesen, D., Stokes, C.R., Bøe, R., Longva, O., Thorsnes, T., Olesen, O., Bugge, T., Lepland, A. \& Hestvik, O.B., 2016. Landform assemblages and sedimentary processes along the Norwegian Channel Ice Stream. Sedimentary Geology 338, 1, 115-137. https://doi.org/10.1016/j.sedgeo.2016.01.024

Palmu, J.-P., Ojala, A.E.K., Ruskeeniemi, T., Sutinen, R. \& Mattila, J., 2015. LiDAR DEM detection and classification of postglacial faults and seismically-induced landforms in Finland: a paleoseismic database. GFF 137, 344-352. https://doi.org/10.1080/11035897.2015.1068370

Putkinen, N. \& Lunkka, J., 2008. Ice stream behaviour and deglaciation of the Scandinavian Ice Sheet in the Kuittijarvi area, Russian Karelia. Bulletin of the Geological Society of Finland 80, 19-37.

Putkinen, S., Putkinen, N., Sarala, P., Palmu, J.-P., Ojala, A.E.K. \& Ahtonen, N., 2016. Map database of superficial deposits and glaciodynamic features in Finland - methodology and classifications. 32nd Nordic Geological Winter Meeting, Helsinki, Finland, 1315 January 2016. Bulletin of the Geological Society of Finland, Special volume 1, p. 310.

Ross, M., Campbell, J.E., Parent, M. \& Adams, R.S., 2009. Palaeo-ice streams and the subglacial landscape mosaic of the North American mid-continental prairies. Boreas 38, 421-439. https://doi.org/10.1111/j.1502-3885.2009.00082.x

Rydningen, T.A., Vorren, T.O., Laberg, J.S. \& Kolstad, V., 2013. The marine-based NW Fennoscandian ice sheet: glacial and deglacial dynamics as reconstructed from submarine landforms. Quaternary Science Reviews 68, 126-141. https://doi.org/10.1016/j.quascirev.2013.02.013

Sarala, P., 2003. Ribbed-moreenit - jäätikön liikesuunnan poikittaiset indikaattorit. Summary: moraines - transverse indicators of the ice flow direction. Geologi 55, 250-253.

Sarala, P., 2006. Ribbed moraine stratigraphy and formation in southern Finnish Lapland. Journal of Quaternary Science 21, 387-398.

https://doi.org/10.1002/jqs.995

Sarala, P., 2015. Surficial geochemical exploration methods. In: Mayer, W.D., Lahtinen, R. \& O’Brien, H. (eds.), Mineral deposits of Finland. Chapter 10.1. Elsevier, Amsterdam, pp. 711-731.

Sarala, P. \& Räisänen, J., 2017. Evolution of the eastern part of the Kuusamo Ice Lobe based on geomorphological interpretation of high-resolution LiDAR data. Bulletin of the Geological Society of Finland. This volume. 
Sarala, P., Räisänen, J., Johansson, P. \& Eskola, K.O., 2015. Aerial LiDAR analysis in geomorpho-logical mapping and geochronological determination of surficial deposits in the Sodankylä region, northern Finland. GFF 137, 293-303. https://doi.org/10.1080/11035897.2015.1100213

Scheiber, T., Fredin, O., Viola, G., Jarna, A., Gasser, D. \& Łapińska-Viola, R., 2015. Manual extraction of bedrock lineaments from high-resolution LiDAR data: methodological bias and human perception. GFF 137, 362-372. https://doi.org/10.1080/11035897.2015.1085434

Skyttä, P., Kinnunen, J., Palmu, J.-P. \& Korkka-Niemi, K., 2015. Bedrock structures controlling the spatial occurrence and geometry of $1.8 \mathrm{Ga}$ younger glacifluvial deposits - Example from First Salpausselkä, southern Finland. Global and Planetary Change 135, 66-82. https://doi.org/10.1016/j.gloplacha.2015.10.007

Sookhan, S., Eyles, N. \& Putkinen, N., 2016. LiDAR-based volume assessment of the origin of the Wadena Drumlin Field, Minnesota, USA. Sedimentary Geology 338, 7283.

https://doi.org/10.1016/j.sedgeo.2016.01.003
Spagnolo, M., Phillips, E., Piotrowski, J. A., Rea, B.R., Clark, C.D., Stokes, C.R., Carr, S.J., Ely, J.C., Ribolini, A., Wysota, W. \& Szuman, I., 2016. Ice stream motion facilitated by a shallow-deforming and accreting bed. Nature communications 7, 10723. https://doi.org/10.1038/ncomms10723

Stokes, C.R., Spagnolo, M., Clark, C.D., Cofaigh, C.Ó., Lian, O.B. \& Dunstone, R.B., 2013. Formation of mega-scale glacial lineations on the Dubawnt Lake Ice Stream bed: 1. size, shape and spacing from a large remote sensing dataset. Quaternary Science Reviews 7, 190-209. https://doi.org/10.1016/j.quascirev.2013.06.028

Sutinen, R., Hyvönen, E., Middleton, M. \& Ruskeeniemi, T., 2014. Airborne LiDAR detection of postglacial faults and Pulju moraine in Palojärvi, Finnish Lapland. Global and Planetary Change 115, 24-32. https://doi.org/10.1016/j.gloplacha.2014.01.007

Yu, P., Eyles, N. \& Sookhan, S., 2015. Automated drumlin volume estimation using LiDAR curvature imagery: a test from the Wadena Drumlin Field, Minnesota. Geomorphology 246, 589-601. https://doi.org/10.1016/j.geomorph.2015.07.020 